\title{
Scaling-up individual-level allometric equations to predict stand-level fuel loading in Mediterranean shrublands
}

\author{
Miquel De Cáceres $^{1,2}$ (D) $\cdot$ Pere Casals $^{1} \cdot$ Eva Gabriel $^{3} \cdot$ Xavier Castro $^{3}$ \\ Received: 22 January 2019 / Accepted: 7 August 2019/Published online: 22 August 2019 \\ (C) INRA and Springer-Verlag France SAS, part of Springer Nature 2019
}

\begin{abstract}
- Key message Allometric biomass equations developed for individual shrubs can be applied to estimate shrubland fuels from measurements of cover and average height by species.

- Context Shrubs are a major component of surface fuels in many fire-prone ecosystems. Shrub fuel loading is often estimated by "double sampling", where data from a destructive vegetation survey is used to model vegetation-fuel relationships (development phase), and these relationships are then applied to vegetation data from a second survey (application phase). Vegetation-fuel relationships can be modeled at different levels of vegetation detail, from individual plants to stands, but the increased effort of detailed measurements may compromise large-scale applications.

- Aims To facilitate fuel loading assessments in Mediterranean shrublands, we present and test a novel method to estimate standlevel shrub loading that consists in applying individual-level allometric equations to vegetation plot data collected by measuring the percent cover and mean height of each shrub species.

- Methods We used individual-level data (i.e., plant dimensions and dry weights) to develop allometric equations for total and fine (leaves and branches $<6 \mathrm{~mm}$ ) biomass of 26 Mediterranean shrub species. We then evaluated the accuracy and precision of the proposed method in comparison to an approach assuming constant bulk density, using data from 131 vegetation plots and taking as benchmark stand-level loading estimates derived by aggregation of individual biomass allometric estimates. A second set of 13 plots was used to quantify the additional error derived from visual estimation of species mean height and cover.

- Results The performance of species-specific models was acceptable in estimating total and fine biomass at the individual level. When based on species mean height and cover data, stand-level fuel loading estimates calculated using the proposed method had a better precision and accuracy than those obtained using bulk density values ( -4 vs. $+39 \%$ in relative bias; 10 vs. $40 \%$ in relative MAE). Visual estimation of species mean height and percent cover led to 10 and $16 \%$ increase in MAE for species loading estimates of total and fine fuels, respectively, with respect to estimates obtained without this source of error.

- Conclusions Our approach to estimate shrub loading allows combining fast species-level vegetation sampling with the flexibility of individual-level allometries to model to size-related variations of bulk density.
\end{abstract}

Keywords Bulk density · Fine fuels · Fuel loading · Fuel mapping · Vegetation sampling

\section{Handling Editor: Paulo Fernandes}

Contribution of co-authors $\mathrm{PC}, \mathrm{XC}$, and EG coordinated field sampling. MCA and PC conducted the analyses and led manuscript writing, with contributions from all co-authors.

Miquel De Cáceres

miquelcaceres@gmail.com

1 Joint Research Unit CTFC - AGROTECNIO, Crta. de St. Llorenç de Morunys, km 2,, 25280 Solsona, Spain
Centre for Ecological Research and Forestry Applications (CREAF), 08193 Cerdanyola del Valles, Spain

3 Servei de Prevenció d'Incendis Forestals, Departament d'Agricultura Ramaderia, Pesca i Alimentació, Generalitat de Catalunya, 08130 Santa Perpètua de Mogoda, Spain 


\section{Introduction}

Shrubs are a major component of surface fuels in many fireprone ecosystems such as shrublands, encroached grasslands, woodlands, and forests, especially under low tree density (Sabo et al. 2009; Coll et al. 2011). Key shrub fuel descriptors such as loading, bulk density, dead-to-live ratio, and moisture are required inputs to wildfire behavior models (Keane 2015). Due to their high rate of energy exchange, shrub fine fuels (i.e., leaves and fine branches $<6 \mathrm{~mm}$ diameter) are particularly important to fire ignition and spread (Pyne 1984). Properties of shrub fine fuels are related not only to shortterm meteorological conditions but also to long-term responses to natural (e.g., drought, browsing, tree canopy cover) and anthropogenic (e.g., management) factors (Castro et al. 2003; Pimont et al. 2018; Ruffault et al. 2018). Moreover, shrub fuel properties exhibit a strong interspecific variation. For example, Pistacia lentiscus L. always has a low percentage of twigs in relation to total biomass, and Genista scorpius (L.) DC. in Lam. et DC. has a high proportion of standing dead material (Papió and Trabaud 1991). Fuel properties have been linked to functional species groups related to post-fire regeneration strategies (Saura-Mas et al. 2010; Vilagrosa et al. 2014). The diversity of morphological, physiological, and phenological traits of woody plant species coexisting in the shrub complex results in high spatial and temporal heterogeneity of fuel properties.

Fuel load (i.e., dry weight of fuel per surface area) is arguably the most important property when studying wildland fuels, and it can be estimated using a panoply of approaches (Keane 2015). Although destructive methods, such as clipping and weighting, are generally the most accurate to estimate fuel load of shrub complexes, they are also expensive and time consuming (Catchpole and Wheeler 1992; Bonham 2013). Since destructive sampling is inefficient when the goal is to make an inventory of shrub fuels over large spatial extents or to monitor their dynamics over time (Keane 2015), the so called "double sampling" approaches are often adopted. The first sampling phase involves collecting a number of destructive samples to model the relationship between fuel load and previously measured vegetation dimensions. This relationship can then be applied in a second sampling phase where vegetation dimensions are either measured in field campaigns or obtained through remote sensing (Kerr and Ostrovsky 2003). Different kinds of relationships have been developed for different levels of detail in vegetation sampling (Catchpole and Wheeler 1992), from individual plant measurements to standlevel measurements of vegetation cover and height (Fig. 1).

At the individual level, allometric equations are commonly used to estimate plant biomass from individual plant measurements (usually crown dimensions, plant height, or basal stem diameter; see arrow "1-1" in Fig. 1). Allometric relationships for shrub species have been developed in different regions to estimate both total biomass (Armand et al. 1993; Usó et al. 1997; Blanco-Oyonarte and Navarro-Cerrillo 2003; Conti et al. 2013) and fine fuel fractions (Pereira et al. 1995; Paton et al. 2002; Huff et al. 2017). Despite being flexible enough to accommodate variations in bulk density related to plant size, allometric equations have some limitations. They may not have the same predictive ability in all sites where the species occurs, as a result of either different environmental conditions (e.g., forest canopy cover; browsing; fire) or genetic factors affecting plant morphology (Catchpole and Wheeler 1992; López-Serrano et al. 2005; Ritchie et al. 2013; Pimont et al. 2018). Moreover, it often happens that species-specific equations are lacking for some of the species found in the target area. This can be solved using allometries developed for morphologically or functionally similar species groups (Conti et al. 2013; Casals et al. 2016). However, the potential decrease in the predictive ability incurred by using allometries derived from group-specific instead of species-specific relationships needs to be quantified (Sah et al. 2004).

Identifying and tallying all individual woody plants in fixed area plots becomes expensive for large-scale fuel surveys, which leads to the development of vegetation-fuel relationships at coarser levels. Habitat-specific empirical relations to predict shrub fuel loading can be fitted from stand-level measurements such as visual estimates of total cover, mean height, or apparent volume of the shrub layer (Pasalodos-Tato et al. 2015) (see arrow "3-3" in Fig. 1). These relationships are faster to apply than approaches requiring individual plant measurements and are interesting because of the possibility to obtain estimates over large areas with remote sensing technologies (Kerr and Ostrovsky 2003). Nevertheless, empirical relationships developed from stand-level data may have low predictive ability due to spatial variability in species composition (even within the same habitat) and between-species differences in size-biomass relationships.

Between the individual and stand levels of vegetation sampling detail lies the species level, which consists in estimating dimensions of each species in the study plot, such as species mean height and cover. Species-level data have the advantage of allowing between-species morphological variability to be accounted for. Developing approaches to estimate fuel loading from species data is appealing because mean height and percent cover of understory species are routinely recorded in national forest inventory surveys (e.g., Villanueva 2004). To obtain loading estimates from species data, one can calculate the apparent volume occupied by each species and multiply it by species-specific bulk density values (Fernandes 2009) or use an allometric relationship similar to stand-level approaches (Porté et al. 2009; Ruiz-Peinado et al. 2013) (see arrow "2-2" in Fig.1).

With the aim to facilitate regional assessments of fuel loading (or forage availability, or carbon stock) in Mediterranean shrublands, the main goal of this study is to present and 


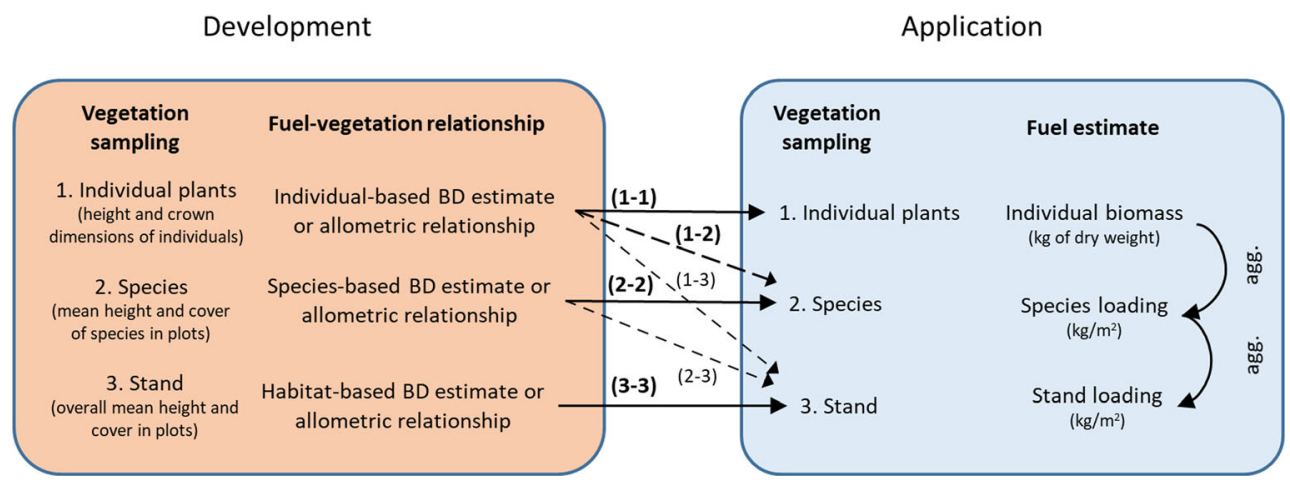

Fig. 1 Conceptual diagram to illustrate different ways to estimate fuel loading by "double sampling" (i.e., first sampling phase to obtain data to model fuel-vegetation relationships and second sampling phase where such relationships are applied). Continuous arrows ("1-1," "2-2," and "3-3") indicate "double sampling" approaches in which the two phases are conducted with the same detail of vegetation sampling. The approach evaluated in this paper is indicated using a thick dashed arrow ("1-2"), implying a development phase at the individual level and an application at the species level. Other approaches (i.e., thin dashed arrows "1-3" and "23") are mentioned in the "Discussion" section. BD stands for "bulk density." Fuel loading estimates at species/stand levels may be obtained by aggregation (agg.) of estimates obtained at lower levels evaluate a method to estimate shrub loading that consists in developing allometric equations at the individual level and applying them to vegetation plot data sampled by measuring percent cover and mean height of each species (see arrow "12 " in Fig. 1). We start with the development of individuallevel allometric equations for total fuel biomass, fine fuel biomass, and crown projected area of 26 shrub species of the target region (Catalonia; NE of Spain). For those species sampled in more than one site, we compare the performance of species-specific vs. site-specific equations. We also assess the loss of predictive capacity when allometries are calibrated for functional groups. After that, we detail the proposed method to estimate fuel loading and we use data from 131 vegetation plots to evaluate its predictive capacity in comparison to an approach assuming constant species bulk density. Finally, we use a second set of 13 plots to quantify the additional error derived from visual estimation of species mean height and percent cover.

\section{Material and methods}

\subsection{Study area}

The study area is Catalonia (NE of Iberian Peninsula; Fig. 2). The region is highly mountainous with the exception of the southwestern plains of the Ebro basin. Elevation ranges from sea level up to $3000 \mathrm{~m}$, with a mean elevation of about $700 \mathrm{~m}$. Soil parent materials are most commonly limestones and marls, though low metamorphic schists and granodiorites are also frequent in the north and north-east and evaporites in the central-western area. Mediterranean is the dominant climate, but climatic variation is high following variation in topography and continentality.

\subsection{Target species and vegetation sampling}

Our dataset for calibration of fuel allometries is a collection of destructive individual-level field data obtained by different research groups (Table 4 Appendix 1). The selection of species aims to include the most common shrubs in Catalonia. Specimens were sampled in a single location, but in nine species specimens include two or three sampling locations to account for geographic variation of morphology (Table 4 Appendix 1). The dataset includes 26 species belonging to three plant forms: Macro-phanerophytes, nano-phanerophytes, and chamaephytes (Table 5 Appendix 1). Nanophanerophytes are, in turn, split on the basis of their postfire regeneration strategy (i.e., obligate seeders, facultative seeders, and resprouters), according to Paula et al. (2009).

\subsection{Development of allometric equations}

Power functions are often used to study the relationship between individual volume and its corresponding total or fine fuel biomass (Armand et al. 1993; Pereira et al. 1995; Paton et al. 2002; Ruiz-Peinado et al. 2013). The following functions were used to model total dry weight $\left(B_{\text {total }} ;\right.$ in $\mathrm{kg}$ ) and fine fuel dry weight $\left(B_{\text {fine }}\right.$; in $\mathrm{kg}$ ) of individuals:

$B_{\text {total }}=a_{\text {total }} \cdot V^{b_{\text {total }}}$

$B_{\text {fine }}=a_{\text {fine }} \cdot V^{b_{\text {fine }}}$

where $V$ is the apparent shrub volume (in $\mathrm{m}^{3}$ ) assuming the shape of an elliptic cylinder, and $a_{\text {total }}, a_{\text {fine }}, b_{\text {total }}$, and $b_{\text {fine }}$ are species-specific (or group-specific) parameters. Parameter $a$ represents the bulk density for a shrub of $1 \mathrm{~m}^{3}$, so its value depends on how volume is defined (Pereira et al. 1995). We did not consider alternative forms of solid bodies for the calculation of apparent volume (Blanco-Oyonarte and Navarro- 
Fig. 2 Map of the location of the $13110 \times 10-\mathrm{m}$ plots distributed across the western and central parts of Catalonia (NE Spain) and used for the evaluation of the proposed loading estimation method. Colors indicate the elevation at the plot site (gray indicates a missing elevation value) and shapes correspond to habitat classes

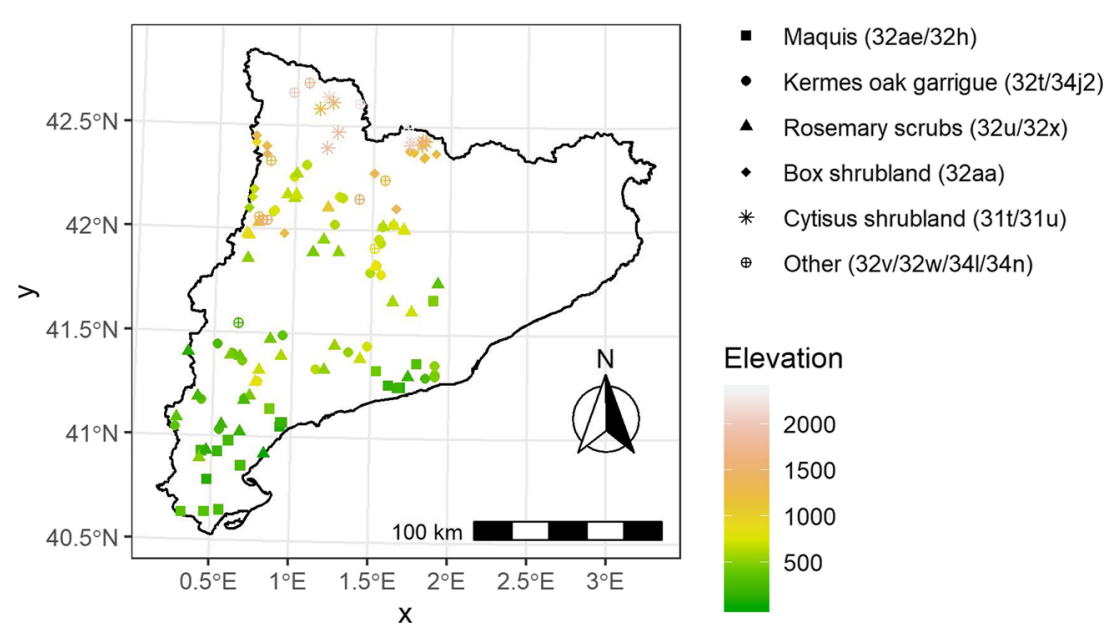

Cerrillo 2003), because this often leads to proportional $a$ values (Usó et al. 1997). Parameter $b$ represents the degree of isometry/allometry in the relationship between volume and biomass. It can be understood as the ratio between relative biomass increments and relative volume increments, with values below one indicating that bulk density decreases with plant volume (Armand et al. 1993).

Coefficients for volume-biomass allometries were obtained by fitting generalized linear models (GLMs) with a logarithm link function and assuming Gamma-distributed errors (McCullagh and Nelder 1989):

$$
\begin{aligned}
\log (E(B))= & \log (a)+b \\
& \cdot \log (V) \quad \text { with } B \sim \operatorname{Gamma}(\mu, \nu)
\end{aligned}
$$

where $\mu=E(B)$ and $\nu$ are the mean and dispersion parameters of the Gamma distribution, respectively. GLMs directly fit the expected mean of the dependent variable, hence avoiding the biases of log-log linear regressions (McCullagh and Nelder 1989). The predictive value of allometric equations was assessed by calculating the cross-validated (leave-one-out) bias, mean absolute error (MAE), and coefficient of determination $\left(R^{2}\right)$ between the predicted and observed individual biomass. For the nine species where different locations had been sampled, we evaluated the degree of generality of speciesspecific allometries by comparing them to models including the location factor as potentially affecting both the intercept and the slope of the relationship:

$$
\begin{aligned}
\log (E(B))= & \log \left(a_{l}\right) \cdot L+b_{l} \cdot \log (V) \\
& \cdot L \quad \text { with } B \sim \operatorname{Gamma}(\mu, \nu)
\end{aligned}
$$

where $L$ is an indicator variable of location, and $a_{l}$ and $b_{l}$ are location-specific parameters. Models fitted by either Eq. (2) or (3) were compared in terms of predictive value and by means of a likelihood ratio chi-square test. We also evaluated to which extent allometric equations calibrated after grouping the species into functional groups had similar or worse predictive capacity than species-specific allometries. For that, we fitted group-specific allometric equations (Eqs. (1) and (2)), again using GLMs with logarithm link and Gamma distribution of errors. As before, we compared the models of Eqs. (2) and (3), but replacing the role of location by that of species identity.

\subsection{Application of the individual-level allometries to species-level data}

When vegetation data consist in mean height $\left(H_{m}\right.$; in $\left.\mathrm{cm}\right)$ and the percent cover $(C$; in \%) per shrub species, we suggest to calculate species fuel loading $\left(\mathrm{kg} \mathrm{m}^{-2}\right)$ by applying the allometries developed at the individual level to an "average" individual and multiply the resulting biomass by an estimation of plant density. This requires developing an additional allometry to estimate the projected crown area $\left(C A ; \mathrm{cm}^{2}\right)$ of individuals from their height $H(\mathrm{~cm})$ :

$\mathrm{CA}=a_{\text {area }} \cdot H^{b_{\text {area }}}$

where, as before, $a_{\text {area }}$ and $b_{\text {area }}$ are species-specific (or groupspecific) parameters. Applying Eq. (4) on $H_{m}$ provides $C A_{m}$, the area occupied by an average individual. Multiplying $H_{m}$ by $C A_{m}$ (after expressing them in $\mathrm{m}$ and $\mathrm{m}^{2}$, respectively), one obtains the apparent volume of the average individual $\left(V_{m}\right.$; in $\mathrm{m}^{3}$ ). Biomass allometries (Eq. (1)) can then be applied to obtain $B_{\text {total, } m}$ or $B_{\text {fine, } m}$ estimates corresponding to the average individual. Note that the whole process is equivalent to a single allometric equation relating biomass to height, which in the case of $B_{\text {total, } m}$ is

$$
\begin{aligned}
B_{\text {total }, m} & =a_{\text {total }} \cdot\left(H_{m} \cdot C A_{m}\right)^{b_{\text {total }}} \\
& =a_{\text {total }} \cdot\left(a_{\text {area }}\right)^{b_{\text {total }}} \cdot\left(H_{m}\right)^{\left(1+b_{\text {area }}\right) \cdot b_{\text {total }}} .
\end{aligned}
$$


Finally, the loading of the species in the target area $(W$; in $\mathrm{kg} \mathrm{m}^{-2}$ ) is estimated as the product of $B_{\text {total }, m}$ or $B_{\text {fine, } m}$ and $N$, an estimate of density of individuals (in $\mathrm{m}^{-2}$ ) derived from percent cover:

$$
\begin{aligned}
& N=(C \cdot 100) / C A_{m} \\
& W_{\text {total }}=N \cdot B_{\text {total }, m} \\
& W_{\text {fine }}=N \cdot B_{\text {fine }, m}
\end{aligned}
$$

We estimated parameters $a_{\text {area }}$ and $b_{\text {area }}$ of Eq. (4) by fitting GLMs with Gamma errors (Eqs. (2) and (3)). We fitted Eq. (4) and not Eq. (5) because explicit $C A_{m}$ estimates are needed for Eq. (6). Crown area allometries were evaluated with the same procedure used for fuel biomass.

\subsection{Evaluation of the proposed method}

We evaluated the performance of the method presented in the previous section using data from $13110 \times 10$-m plots distributed across the eastern and central parts of Catalonia (Fig. 2) and surveyed by forest rangers ("Cos d'Agents Rurals de la Generalitat de Catalunya"). On each plot, rangers tallied all shrub individuals (height and crown dimensions) within two $90^{\circ}$-angle belt transects of $10 \mathrm{~m}$ length and $1 \mathrm{~m}$ width. Individual-level biomass estimates were obtained using plant measurements to calculate shrub volume $(V)$, as explained in Appendix 1, and applying Eq. (1) with species- or groupspecific allometric coefficients (Table 6 Appendix 2). Biomass estimates were then aggregated into species and stand loading values (in $\mathrm{kg} \mathrm{m}^{-2}$ ), which were taken as benchmarks to evaluate the predictive value of estimates derived from species-level data.

Estimates of mean height $\left(H_{m}\right)$ and percent cover $(C)$ by species were calculated from individual-level measurements: $H_{m}$ was calculated as a weighted average of individual heights, using crown area as weight, whereas $C$ was calculated as the sum of crown areas and expressed in percent of the sampled area $\left(20 \mathrm{~m}^{2}\right)$. One species cover value exceeded $100 \%$ due to crown overlap and was truncated. These species-level estimates contain very little measurement error, so they are appropriate to assess the predictive capacity of loading estimation methods while controlling for sampling uncertainty (see next section). We compared the performance of two approaches to estimate species and stand fuel loading:

1. Bulk density: We multiplied $C$ and $H_{m}$ to obtain a species apparent volume per square meter, which we then multiplied by the species-specific (or group-specific) mean bulk density values (Table 5 Appendix 1).

2. Up-scaled allometries: We estimated the $C A_{m}$ from $H_{m}$, using species-specific (or group-specific) crown area allometries (Eq. (4); Table 6 Appendix 2). Biomass values for "average individuals" were then estimated using (species- or group-specific) allometries (Eq. (1); Table 6 Appendix 2). Finally, species loadings were obtained using Eqs. (6) and (7).

We assessed the predictive value of the two approaches by calculating bias, mean absolute error (MAE), and coefficient of determination $\left(\mathrm{R}^{2}\right)$ of the resulting species and stand loading estimates with respect to the benchmark values.

\subsection{Quantification of the error derived from visual vegetation sampling}

Estimates of species $C$ and $H_{m}$ contain more or less measurement error depending on the sampling method (Catchpole and Wheeler 1992; Bonham 2013). To address the effect of this additional source of error, we selected a second set of $135 \times$ $5 \mathrm{~m}$ vegetation plots where vegetation sampling was conducted both at the individual level (tallies) and at the species level (visually). Species visual $C$ and $H_{m}$ estimates were made by three different researchers and were averaged to decrease observer bias. We compared the predictive performance of our proposed loading estimation method from either (a) species data obtained by aggregation of individual measurements (as in the previous section) or (b) species data estimated visually. As before, benchmarks for the evaluation were species loadings obtained from aggregation of individual biomass estimates.

\section{Results}

\subsection{Performance of individual-level allometric equations}

Bulk density of sampled individuals varied broadly among species and individuals, with species mean values ranging between $0.26 \mathrm{~kg} \mathrm{~m}^{-3}$ (Viburnum tinus) and $7.94 \mathrm{~kg} \mathrm{~m}^{-3}$ (Thymus vulgaris) for total biomass and between $0.21 \mathrm{~kg} \mathrm{~m}^{-3}$ (V. tinus) and $3.22 \mathrm{~kg} \mathrm{~m}^{-3}$ (Cistus laurifolius) for fine fuel biomass (Table 5 Appendix 1). Cross-validated predictive performance of individual-level allometries was highest for total biomass $\left(W_{\text {total }}\right.$, relative $\mathrm{MAE}=36 \%$; rel. bias $\left.+6 \% ; R^{2}=0.84\right)$, closely followed by fine fuel biomass $\left(W_{\text {fine }}\right.$; rel. $\mathrm{MAE}=43 \%$; rel. bias $+4 \% ; \mathrm{R}^{2}=0.75$ ), whereas the worst performance was obtained for crown area allometries $(C A$; rel. MAE $=56 \%$; rel. bias $\left.+5 \% ; \mathrm{R}^{2}=0.58\right)($ Table 1$)$. The predictive performance of allometries decreased when calibrating equations for functional groups, leading to an $+18-20 \%$ increase in MAE for biomass estimates and a $+6 \%$ increase for crown area estimates, with respect to species-specific models (Table 1). Table 6 Appendix 2 includes details of fitted allometric coefficients and cross-validated predictive performance 
Table 1 Cross-validated predictive performance (mean absolute error [MAE], bias, and coefficient of determination $\left[\mathrm{R}^{2}\right]$ ) of individual-level allometric equations for total biomass, fine fuel biomass, and projected crown area. The first two rows show the predictive performance of species- and group-specific allometries. The predictive performance of the nine species subset with different populations sampled is shown in the last two rows, including or not the location factor. Table 6 shows the allometric coefficients and predictive performance for every species and functional group

\begin{tabular}{|c|c|c|c|c|c|c|c|c|c|c|}
\hline \multirow[b]{2}{*}{$\begin{array}{l}\text { Allometries fitted } \\
\text { by... }\end{array}$} & \multirow[b]{2}{*}{$n$} & \multicolumn{3}{|c|}{ Total biomass $\left(B_{\text {total }}\right)$} & \multicolumn{3}{|l|}{ Fine fuels $\left(B_{\text {fine }}\right)$} & \multicolumn{3}{|c|}{ Crown area $(C A)$} \\
\hline & & $\operatorname{MAE}(\mathrm{kg})[\%]$ & Bias $(\mathrm{kg})[\%]$ & $\mathrm{R}^{2}$ & $\operatorname{MAE}(\mathrm{kg})[\%]$ & Bias $(\mathrm{kg})[\%]$ & $\begin{array}{l}\mathrm{R}^{2} \\
(\%)\end{array}$ & $\begin{array}{l}\text { MAE }\left(\mathrm{cm}^{2}\right) \\
{[\%]}\end{array}$ & Bias $\left(\mathrm{cm}^{2}\right)[\%]$ & $\begin{array}{l}\mathrm{R}^{2} \\
(\%)\end{array}$ \\
\hline Species & 795 & $0.438[36.0 \%]$ & $+0.070[+5.7 \%]$ & 0.839 & $0.284[42.6 \%]$ & $+0.028[+4.2 \%]$ & 0.751 & $4291[56.1 \%]$ & $+372[+4.9 \%]$ & 0.579 \\
\hline Functional groups & 795 & $0.654[53.8 \%]$ & $-0.072[-5.9 \%]$ & 0.633 & $0.425[62.3 \%]$ & $+0.024[+3.6 \%]$ & 0.446 & $4744[62.1 \%]$ & $+239[+3.1 \%]$ & 0.425 \\
\hline Species (subset) & 431 & $0.374[44.5 \%]$ & $+0.025[+3.0 \%]$ & 0.756 & $0.224[44.1 \%]$ & $+0.009[+1.7 \%]$ & 0.695 & $3291[55.2 \%]$ & $+179[+3.0 \%]$ & 0.602 \\
\hline $\begin{array}{l}\text { Species and } \\
\text { location }\end{array}$ & 431 & $0.357[42.4 \%]$ & $-0.009[-1.1 \%]$ & 0.629 & $0.192[38.0 \%]$ & $-0.018[-3.5 \%]$ & 0.649 & $2888[48.5 \%]$ & $+128[+2.1 \%]$ & 0.577 \\
\hline
\end{tabular}

values for each species and functional group. We found significant differences between location-specific (Eq. (3)) and species-specific (Eq. (2)) models for total biomass in five of the nine species where different localities had been sampled ( $p$-LRT in Table 6 Appendix 2). When location was included, relative MAE decreased from 45 to $42 \%$ for total biomass and from 44 to $38 \%$ for fine fuels (Table 1).

\subsection{Evaluation of the proposed method}

The total number of individuals tallied in the 131 vegetation plots was 6900 , and the number of individuals per plot ranged between 8 and 148. Among all individuals, 72\% belonged to species for which species-specific allometric models were available. The remaining were assigned the allometric parameter values of their corresponding functional group. Total loading in plots ranged from 0.03 to $2.60 \mathrm{~kg} \mathrm{~m}^{-2}$ (average $0.81 \mathrm{~kg} \mathrm{~m}^{-2}$ ) and that of fine fuels from 0.03 to $1.76 \mathrm{~kg} \mathrm{~m}^{-2}$ (average $0.54 \mathrm{~kg} \mathrm{~m}^{-2}$ ).

Calculation of percent cover $(C)$ and mean height $\left(H_{m}\right)$ by species resulted in 830 species records. Species and stand loadings calculated using species-level data and species mean bulk density estimates correlated quite strongly with values obtained from aggregation of individual biomass estimates (Table 2). However, medium and large loading values were

Table 2 Predictive performance (mean absolute error [MAE], bias, and coefficient of determination $\left[\mathrm{R}^{2}\right]$ ) of species and stand loadings calculated from species data using either species mean bulk density values ("bulk density") or the proposed method based on individual-level allometries often overestimated with respect to benchmark values (Fig. 3) and the overall relative bias was $+39 \%$ for total fuel and + $27 \%$ for fine fuel. Estimates derived from the proposed method based on up-scaled allometries were substantially more accurate and precise that those derived from bulk density (Table 2; see also Tables 7 and 8 Appendix 2). MAE of the proposed method was $0.017 \mathrm{~kg} \mathrm{~m}^{-2}(14 \%)$ for total fuel at the species level and $0.082 \mathrm{~kg} \mathrm{~m}^{-2}(10 \%)$ at the stand level, and slightly larger errors occurred for fine fuels. Small negative biases were however observed $(-4 \%$ relative bias for total fuel and $-5 \%$ for fine fuel; Table 2 ).

\subsection{Vegetation sampling effect on loading estimates}

The second dataset of $1325-\mathrm{m}^{2}$ vegetation plots included 518 individuals and 49 species cover/height records. The proposed approach tended to overestimate species loading in this dataset (Table 3; Fig. 4), but the smaller sample size $(n=49)$ leads to performance statistics that have larger variance than in the previous dataset $(n=830)$. Visual estimation of species $C$ and $H_{m}$ produced a moderate increase $+0.022 \mathrm{~kg} \mathrm{~m}^{-2}(+10 \%)$ in MAE for total fuel and $+0.022 \mathrm{~kg} \mathrm{~m}^{-2}(+16 \%)$ for fine fuel; differences in bias were small for both fuel fractions.

("up-scaled allometries"). In all cases, benchmark loadings are those obtained from aggregation of individual biomass estimates. Brackets for MAE and bias indicate relative values

\begin{tabular}{|c|c|c|c|c|c|c|c|}
\hline \multirow[b]{2}{*}{ Fraction } & \multirow[b]{2}{*}{ Method } & \multicolumn{3}{|c|}{ Species loading $(n=830)$} & \multicolumn{3}{|c|}{ Stand loading $(n=131)$} \\
\hline & & $\operatorname{MAE}\left(\mathrm{kg} \mathrm{m}^{-2}\right)[\%]$ & $\operatorname{Bias}\left(\mathrm{kg} \mathrm{m}^{-2}\right)[\%]$ & $\mathrm{R}^{2}$ & $\operatorname{MAE}\left(\mathrm{kg} \mathrm{m}^{-2}\right)[\%]$ & $\operatorname{Bias}\left(\mathrm{kg} \mathrm{m}^{-2}\right)[\%]$ & $\mathrm{R}^{2}$ \\
\hline \multirow[t]{2}{*}{ Total fuel $\left(W_{\text {total }}\right)$} & Bulk density & $0.054[42.9 \%]$ & $+0.049[+38.5 \%]$ & 0.911 & $0.322[39.8 \%]$ & $+0.311[+38.5 \%]$ & 0.900 \\
\hline & Up-scaled allometries & $0.017[13.6 \%]$ & $-0.005[-3.7 \%]$ & 0.971 & $0.082[10.2 \%]$ & $-0.030[-3.7 \%]$ & 0.951 \\
\hline \multirow[t]{2}{*}{ Fine fuel $\left(W_{\text {fine }}\right)$} & Bulk density & $0.037[43.0 \%]$ & $+0.023[+27.3 \%]$ & 0.803 & $0.175[32.4 \%]$ & $+0.147[+27.3 \%]$ & 0.831 \\
\hline & Up-scaled allometries & $0.016[18.7 \%]$ & $-0.004[-4.8 \%]$ & 0.913 & $0.074[13.7 \%]$ & $-0.025[-4.6 \%]$ & 0.879 \\
\hline
\end{tabular}


Fig. 3 Comparison of species and stand loadings calculated from species data using either the average bulk density or the proposed approach based on individual-level allometries. Benchmark loadings ( $y$ axes) are those obtained from aggregation of individual biomass estimates (a) Species total loading

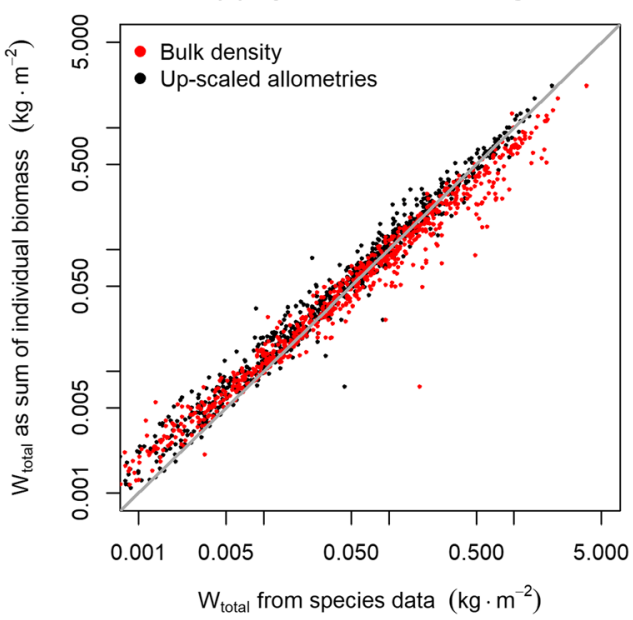

(c) Stand total loading

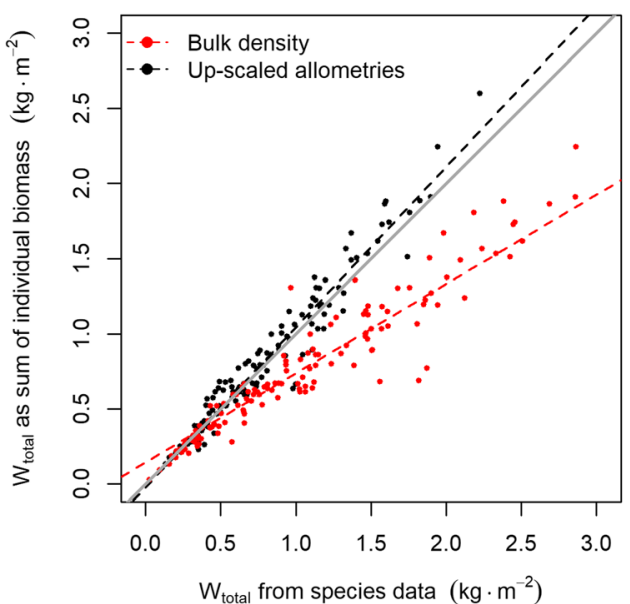

(b) Species fine loading

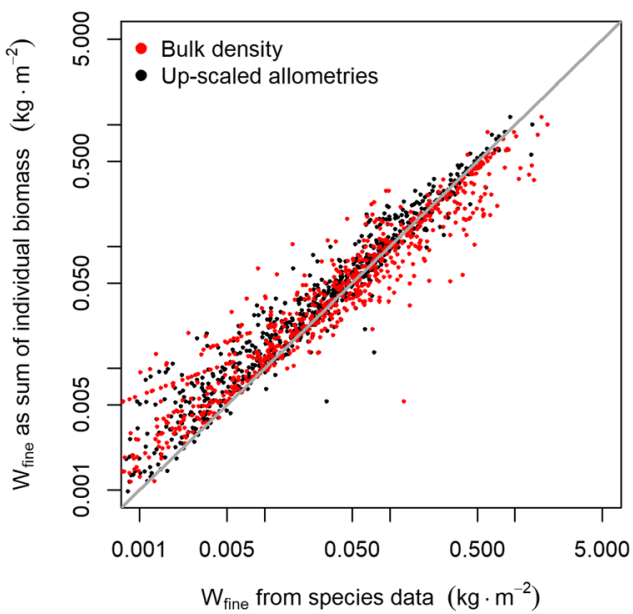

(d) Stand fine loading

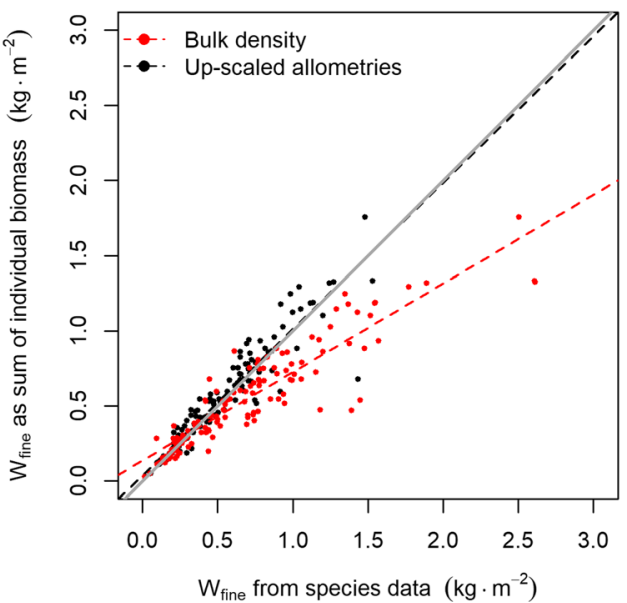

\section{Discussion}

Species-specific allometric models developed at individual level are commonly used as an indirect method to predict biomass when destructive techniques are economically (i.e., time consuming) or scientifically (i.e., repeated inventories) limited (Catchpole and Wheeler 1992; Bonham 2013). The individual-level biomass allometries for 26 Mediterranean species presented here complement existing equations for

Table 3 Predictive performance (mean absolute error [MAE], bias, and coefficient of determination $\left[\mathrm{R}^{2}\right]$ ) of species loadings calculated using the proposed approach based on individual allometries and species mean height and cover data obtained from either aggregation of individual measurements ("individual sampling + aggregation") or visual the same or other shrub species in Iberian Peninsula (Pereira et al. 1995; Castro et al. 1996; Paton et al. 2002; BlancoOyonarte and Navarro-Cerrillo 2003; Castro and Freitas 2009). Individual-level allometries have potential limitations derived from intra-specific or habitat-specific variations and, accordingly, including location as a factor-improved models of total biomass in five of the nine species where different localities had been sampled. Our study was not designed to test location effects, and it is likely that predictive ability of

estimation (visual species sampling). In all cases, benchmark loadings are those obtained from aggregation of individual biomass estimates ( $n=49$ after aggregation). Brackets for MAE and bias indicate relative values

\begin{tabular}{|c|c|c|c|c|}
\hline Fraction & Source of species data & $\operatorname{MAE}\left(\mathrm{kg} \mathrm{m}^{-2}\right)[\%]$ & $\operatorname{Bias}\left(\mathrm{kg} \mathrm{m}^{-2}\right)[\%]$ & $\mathrm{R}^{2}$ \\
\hline \multirow[t]{2}{*}{ Total fuel $\left(W_{\text {total }}\right)$} & Individual sampling + aggregation & $0.077[34.7 \%]$ & $+0.077[+34.4 \%]$ & 0.950 \\
\hline & Visual species sampling & $0.099[44.8 \%]$ & $+0.068[+30.8 \%]$ & 0.838 \\
\hline \multirow[t]{2}{*}{ Fine fuel $\left(W_{\text {fine }}\right)$} & Individual sampling + aggregation & $0.039[27.8 \%]$ & $+0.037[+26.8 \%]$ & 0.966 \\
\hline & Visual species sampling & $0.061[43.8 \%]$ & $+0.038[+27.0 \%]$ & 0.827 \\
\hline
\end{tabular}


Fig. 4 Comparison of species loadings calculated using species mean height and cover values obtained from either aggregation of individual measurements ("individual sampling + aggregation") or visual estimation ("visual species sampling"). Benchmark loadings ( $y$ axes) are those obtained from aggregation of individual biomass estimates (a) Species total loading

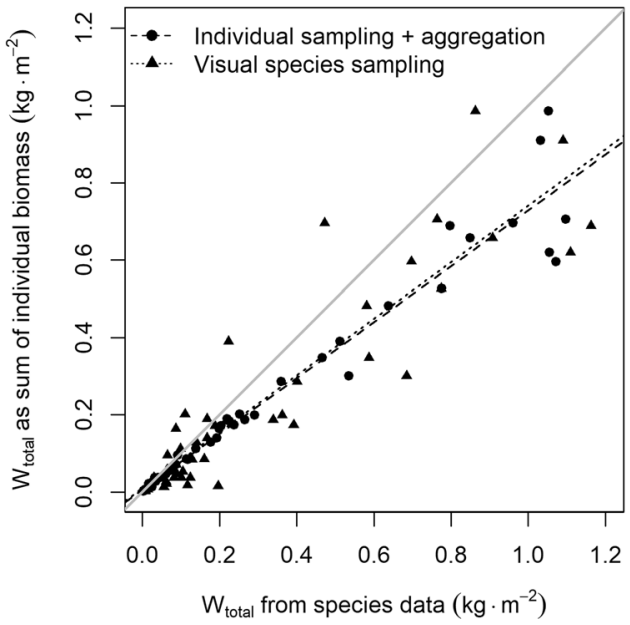

(b) Species fine loading

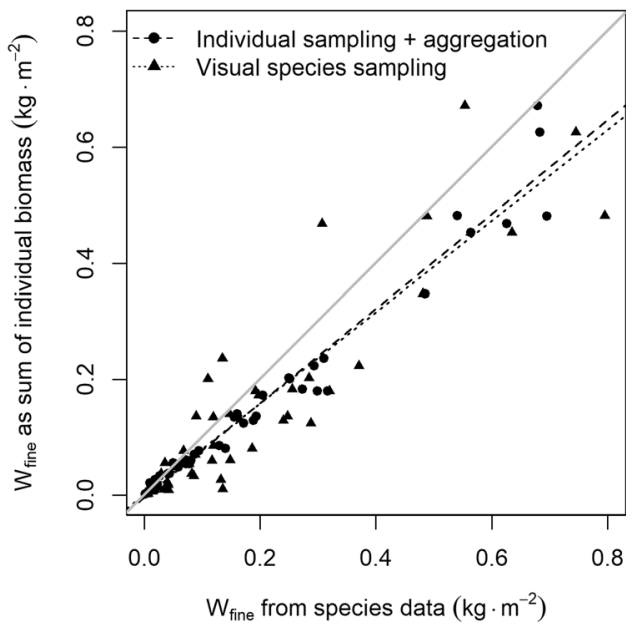

allometries would decrease when applied to localities with micro-environmental conditions different from the habitats sampled in this study. Nevertheless, the overall predictive ability of allometries was only slightly better when considering location-specific parameters (Table 1). The precision of allometries decreased strongly (i.e., higher MAE) when calibrated for functional groups in comparison to species-specific allometries, stressing the need to develop species-specific equations.

We presented an approach to apply our (or other) biomass allometries to estimate fuel loading on vegetation data sampled at the species level. Since bulk density (BD) refers to dry weight per unit volume, applications of bulk density values to estimate fuel loading with vegetation sampling at species or stand levels (i.e., arrows "1-2" or " $1-3$ " in Fig. 1) are not uncommon in fire behavior decision support systems (Ottmar et al. 2007). In contrast to allometric equations, using $\mathrm{BD}$ assumes that plants have an isometric pattern of development between volume and biomass. Values of $b<1$ are very frequent in our allometries, indicating that fuel density decreases with volume for most of our studied species. Therefore, using mean BD estimates instead of allometric regressions at the stand level can lead to large errors if the size of plants is different to that of the plants corresponding to the BD value. Our up-scaled use of allometric equations produced more precise (lower MAE) and accurate (lower bias) loading estimates than calculations based on BD. These results were to be expected because allometric equations account for variations in density derived from variations in plant size. We exemplified our method on allometric equations where the predictor for biomass was shrub volume, but the same strategy could be used to up-scale biomass equations based on other plant measurements, such as crown area, diameter, or height (Paton et al. 2002).

Measuring the dimensions of all woody plants in a plot requires much more effort than estimating mean height and percent cover by species. The main advantage of applying individual-level allometric equations to species-level measurements is that it combines relatively fast vegetation sampling (in the application phase) with the possibility to account for variations in $\mathrm{BD}$ derived from both species identity and plant size. Empirical relationships between stand vegetation variables and fuel loading also require a low amount of sampling effort in their application phase. Appendix 3 shows the comparison of fuel loading estimates obtained using our proposed method with those obtained using the approaches of Fernandes et al. (2012) and Pasalodos-Tato et al. (2015). Although it requires species identification, the comparison indicates that our approach yields more accurate and precise loading estimates, as it profits from information on species composition within each plot and from allometries calibrated for the target region. Species-specific empirical allometries based on the percent cover and mean height of species in fixed stands are also possible (arrow "2-2" in Fig. 1) (Ruiz-Peinado et al. 2013), but such models require a much larger destructive sampling effort in the development phase compared to individual-level allometries. A further advantage of our approach is that a single individual-based destructive survey is enough to fit fuel and crown area allometries, so that the application to species-level data does not require additional destructive surveys.

Despite its advantages, the proposed method comes with some limitations. First, it requires fitting an additional allometry (height vs. crown area), which for many species we found to be of lower predictive value than biomass allometries (Table 6 Appendix 2). For the worst cases, crown area estimates from allometries would not be better than fixed mean crown area values. Wrong crown area $\left(C A_{m}\right)$ estimates can lead to wrong estimates of shrub volume $\left(V_{m}\right)$ and, hence, poor estimates of biomass $B_{\text {total, } m}$ or $B_{\text {fine, } m}$. Second, $C A_{m}$ estimates are also used to derive shrub density from percent cover without accounting for the potential crown overlap 
between individuals (of the same species/group). Third, our approach involves the assumption that the BD of a shrub of "average" height equals the mean BD of all shrubs of the target species in the vegetation plot. Therefore, we expect the predictive value of our approach to be higher in cases where height of individuals of the target species in the plot is homogeneous. Notwithstanding these weaknesses, which may imply an accumulation of estimation errors, we found that our method reduced the error of loading estimates for most species and species groups with respect to assuming constant BD values (Tables 7 and 8 Appendix 2).

In practical applications of our method, estimates of species mean height and percent cover will be more or less accurate depending on the vegetation sampling method. Our results indicate that an additional 10-16\% error should be expected if percent cover and mean height are estimated visually. This increase in error should be evaluated against the benefit of decreasing sampling effort with respect to individual-level measurements. Functions to estimate fuel loading both from individual-level data and from species cover and mean height have been included in the R package "medfuels," which is freely available at GitHub https://github.com/spif-ctfc/ medfuels (De Cáceres et al. 2019).

Acknowledgments We are grateful to AI Ríos, M Sala, JM Blanco, R Vila and the Cos d'Agents rurals and GEPIF (Generalitat de Catalunya) for their help in clipping plants and field measurements. Some species' datasets were kindly provided by Lluís Coll (UdL), Beatriz Duguy (UB), and Joan Romanyà (UB).
Funding This work was supported by the Conselleria d'Agricultura de la Generalitat de Catalunya and the research projects CGL2017-89149-C22-R and RTI2018-098778-B-I00 (Spanish Ministry of Economy and Competitiveness) and by a Spanish "Ramon y Cajal" fellowship to M.D.C (RYC-2012-11109).

Data availability The dataset used to develop individual-based allometries has been included in the R package "medfuels," publicly available as a GitHub repository (https://github.com/spif-ctfc/medfuels) and in the Zenodo repository (De Cáceres et al. 2019) at https://doi.org/10.5281/ zenodo.3356777. The two datasets used for evaluation of the proposed method are available under request.

\section{Compliance with ethical standards}

Conflict of interest The authors declare that they have no conflict of interest.

\section{Appendix 1. Data used to develop individual-level allometries}

Our dataset for the development of fuel allometries is a collection of destructive individual-level field data obtained by different research groups aimed to include the most common shrub species in Catalonia while taking into account some of their geographic variation (Appendix Table 4). Specimens of each target species were sampled in one to three locations, depending on the species.

Table 4 Location, vegetation formation, and research group who measured/collected the individual shrub data. Species names in bold italics indicate species that were sampled in more than one location

\begin{tabular}{|c|c|c|c|}
\hline Location (county) & Species sampled (individuals) & Vegetation formation & Researcher/group \\
\hline Poblet (Conca de Barberà) & Quercus ilex (15), Phillyrea latifolia (15) & Open oak woodland & Marc Taüll \\
\hline Vilamajor (Montsec) & Quercus ilex (20), Q. coccifera (20), Rosmarinus officinalis (20) & Oak shrubland & Marc Taüll \\
\hline El Perelló (1) (Baix Ebre) & $\begin{array}{l}\text { Quercus coccifera (18), Rosmarinus officinalis (20), Pistacia } \\
\quad \text { lentiscus (17), } \\
\text { Ulex parviflorus (20), Erica multiflora (20) }\end{array}$ & Open pine woodland & Beatriz Duguy \\
\hline Trago (Noguera) & Rosmarinus officinalis (50), Genista scorpius (50) & Open shrubland & Pere Casals \\
\hline Odèn (Solsonès) & $\begin{array}{l}\text { Buxus sempervirens (20), Genista scorpius (20), Rosa canina } \\
\quad(20), \text { Thymus vulgaris (20) }\end{array}$ & Encroached grassland & Lluís Coll \\
\hline Collada de Toses (Cerdanya) & Cytisus oromediterraneus $(22)$ & Encroached grassland & Pere Casals \\
\hline Madrona (Solsonès) & Buxus sempervirens (30), Viburnum lantana (30) & Dense pine woodland & $\mathrm{SPIF} / \mathrm{CTFC}$ \\
\hline Madrona (Solsonès) & Ligustrum vulgare (30), Cytisophyllum sessilifolium (30) & Pine forest margin & $\mathrm{SPIF} / \mathrm{CTFC}$ \\
\hline Santa Coloma de Farners (La Selva) & $\begin{array}{l}\text { Arbutus unedo (20), Cistus salviifolius (20), } \\
\text { Erica arborea (12) }\end{array}$ & Open pine woodland & SPIF/CTFC \\
\hline Santa Coloma de Farners (La Selva) & Erica scoparia (20), Cistus salviifolius (20) & Open woodland, dense shrubland & $\mathrm{SPIF} / \mathrm{CTFC}$ \\
\hline Sant Celoni (Vallès Oriental) & Cistus monspeliensis (20) & Open pine woodland & $\mathrm{SPIF} / \mathrm{CTFC}$ \\
\hline Sant Celoni (Vallès Oriental) & Erica arborea (10), Viburnum tinus (20) & Dense pine woodland & SPIF/CTFC \\
\hline El Perelló (2) (Baix Ebre) & Erica multiflora $(10)$ & Open pine woodland & CTFC \\
\hline Begues (Baix Llobregat) & Cistus albidus (20), Erica multiflora (20) & Shrubland & $\mathrm{SPIF} / \mathrm{CTFC}$ \\
\hline Sant Vicenç dels Horts (Baix Llobregat) & Spartium junceum $(20)$ & Shrubland & SPIF/CTFC \\
\hline Castellbò (Alt Urgell) & Cistus laurifolius (20) & Shrubland & CTFC \\
\hline Can Gorgals (La Selva) & Lavandula stoechas $(20)$ & Shrubland & $\mathrm{SPIF} / \mathrm{CTFC}$ \\
\hline Can Gorgals (La Selva) & Cistus monspeliensis (10), Cytisus scoparius (20) & Open pine woodland & SPIF/CTFC \\
\hline
\end{tabular}


For each target species present in a sampling site, several individuals (selected to span a range of sizes) were tallied for crown length at its widest point $\left(L_{M} ; \mathrm{cm}\right)$, the perpendicular crown extent at the same height $\left(L_{P} ; \mathrm{cm}\right)$ and maximum plant height $(H ; \mathrm{cm})$. Each individual was clipped and separated into fine (leaves and $<6 \mathrm{~mm}$ diameter stems) and coarse ( $>$ $6 \mathrm{~mm}$ diameter stems) fuel fractions. Reproductive structures were discarded. Each fraction was weighted in the field (with a precision of 10 and $50 \mathrm{~g}$ for fine and coarse fractions, respectively) and a representative subsample was taken to the lab, where it was weighted again after drying in the oven for $48 \mathrm{~h}$ at $80^{\circ} \mathrm{C}$. The ratio of fresh weight to dry weight of samples was used to obtain the total dry weight $\left(B_{\text {total }}, \mathrm{kg}\right)$ and the dry weight of fine fuels $\left(B_{\text {fine }} ; \mathrm{kg}\right)$ corresponding to each individual. The complete dataset of individual measurements is distributed with package medfuels and is available at Zenodo https://doi.org/10.5281/zenodo.3356777 (De Cáceres et al. 2019).

The projected crown area $\left(C A ; \mathrm{cm}^{2}\right)$ of each individual was calculated assuming an elliptical crown shape:

$\mathrm{CA}=\pi \cdot\left(L_{M} / 2\right) \cdot\left(L_{P} / 2\right)$

We calculated the apparent shrub volume $\left(V ; \mathrm{m}^{3}\right)$ using the shape of a cylinder:

$$
V=C A \cdot H
$$

Bulk density estimates $\left(B D_{\text {fine }}\right.$ and $\left.B D_{\text {total }} ; \mathrm{kg} \mathrm{m}^{-3}\right)$ were obtained dividing the fine or total dry weight by apparent volume and averaged by species and species group. Appendix Table 5 shows the mean and range of the different variables $\left(H, C A, V, B_{\text {fine }}, B_{\text {total }}, B D_{\text {fine }}\right.$, and $\left.B D_{\text {total }}\right)$ for individuals of each species.

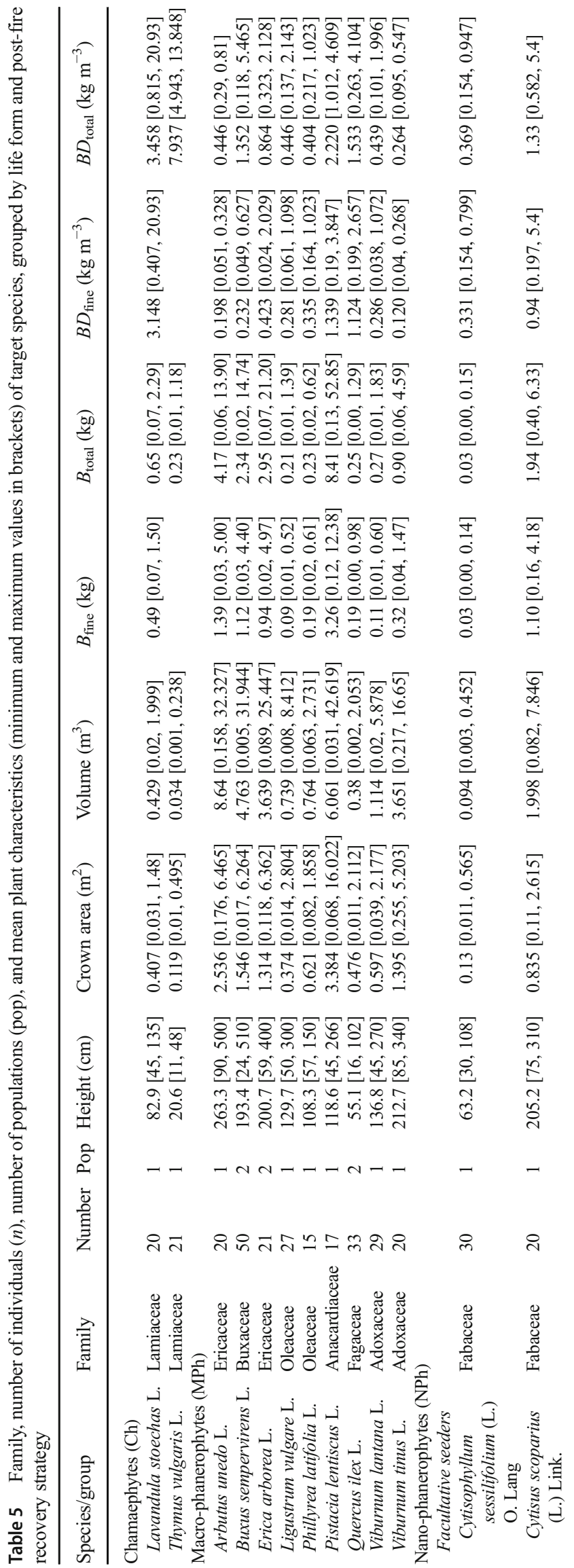




\begin{tabular}{|c|c|c|c|c|c|c|c|}
\hline 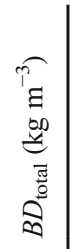 & 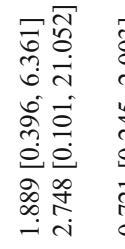 & 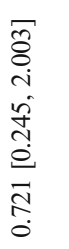 & 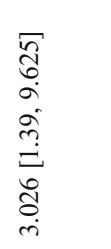 & 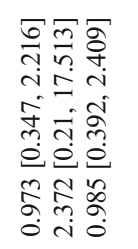 & 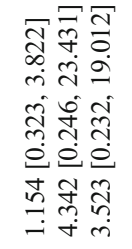 & 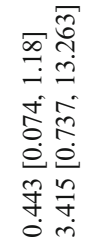 & 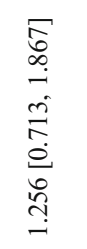 \\
\hline 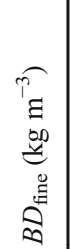 & 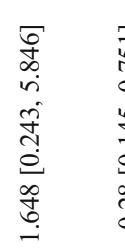 & 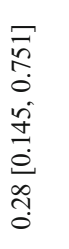 & 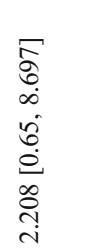 & 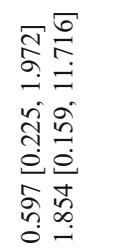 & 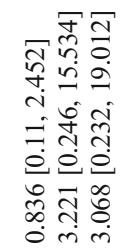 & 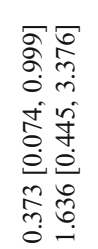 & 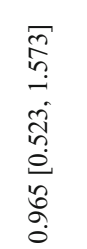 \\
\hline 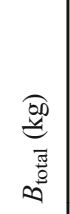 & 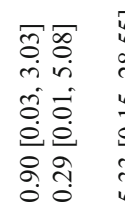 & 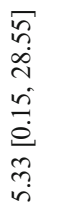 & 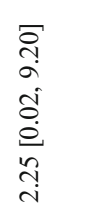 & 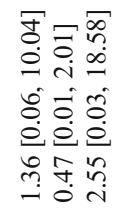 & 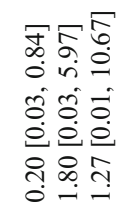 & 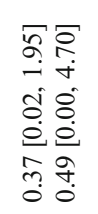 & 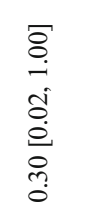 \\
\hline 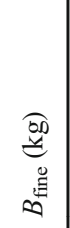 & 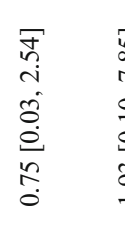 & 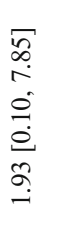 & 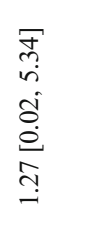 & 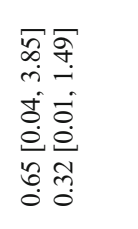 & 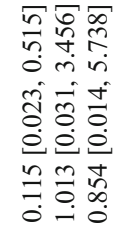 & 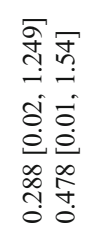 & 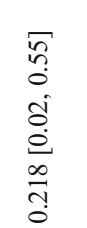 \\
\hline 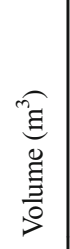 & 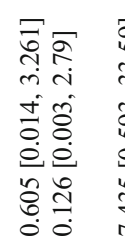 & 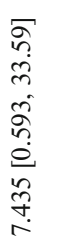 & 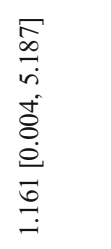 & 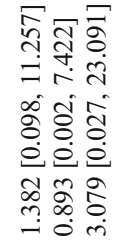 & 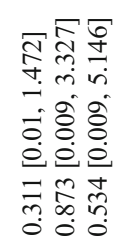 & 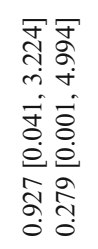 & 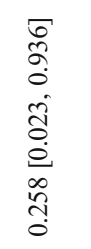 \\
\hline 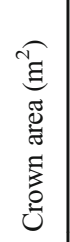 & 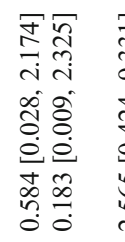 & 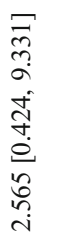 & 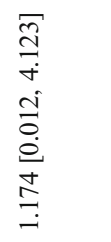 & 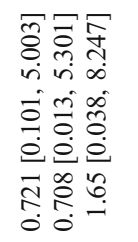 & 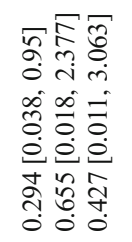 & 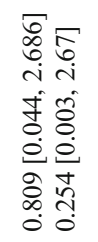 & 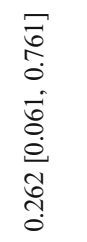 \\
\hline 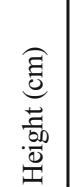 & 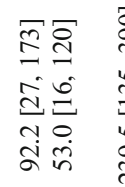 & 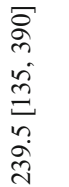 & 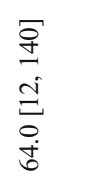 & 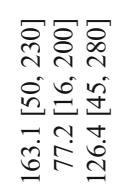 & 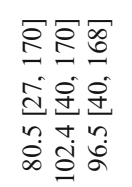 & 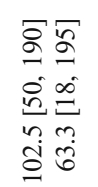 & $\begin{array}{l}\sqrt[\Xi]{\Xi} \\
\dot{\tilde{m}} \\
a \\
\infty \\
\infty\end{array}$ \\
\hline 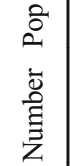 & qे $\&$ & ชิ & ส & ర్లి లి & ్ి్ం & ตेล & $\begin{array}{l}- \\
\stackrel{\text { ¿ }}{-}\end{array}$ \\
\hline 忿 & 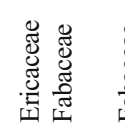 & 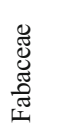 & 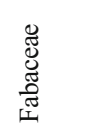 & 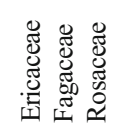 & 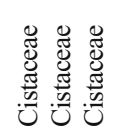 & 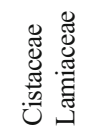 & 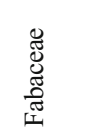 \\
\hline 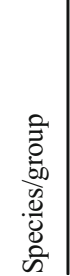 & 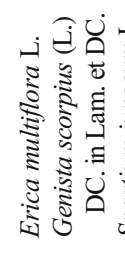 & 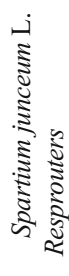 & 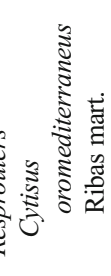 & 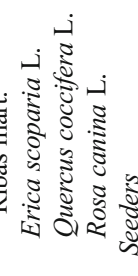 & 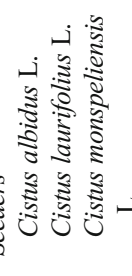 & 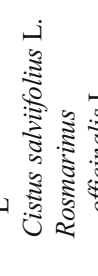 & 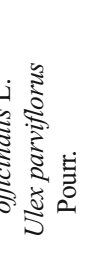 \\
\hline
\end{tabular}




\section{Appendix 2. Supplementary Tables}

Table 6 Allometric regression coefficients ( $a$ and $b$ ) and crossvalidated $\mathrm{R}^{2}$ of the biomass (total and fine fuels) and crown area models fitted for both species and groups. For species, column $R^{2}$ full indicates the cross-validated $\mathrm{R}^{2}$ of a model including location as additional predictor (Eq. (3)) and $p-L R T$ is the $p$ value of a likelihood ratio test between a model without location and a model including it (Eqs. (2) and (3)). For species groups, $p-L R T$ and $R^{2}$ full are the same as before but replacing the role of location by species. Missing values for $p-L R T$ and $R^{2}$ full correspond to cases where either only one location was sampled, the fuel size fractions were not separated in one or more locations, or the species group includes only one species with data

\begin{tabular}{|c|c|c|c|c|c|c|c|c|c|c|c|c|c|c|c|}
\hline \multirow[b]{2}{*}{ Species/group } & \multicolumn{5}{|c|}{ Total biomass $\left(B_{\text {total }}\right)$} & \multicolumn{5}{|c|}{ Fine fuel biomass $\left(B_{\text {fine }}\right)$} & \multicolumn{5}{|c|}{ Crown area $(C A)$} \\
\hline & $a_{\text {total }}$ & $b_{\text {total }}$ & $R^{2}$ & $\begin{array}{l}p- \\
L R T\end{array}$ & $\begin{array}{l}R^{2} \\
\text { full }\end{array}$ & $a_{\text {fine }}$ & $b_{\text {fine }}$ & $R^{2}$ & $\begin{array}{l}p- \\
L R T\end{array}$ & $\begin{array}{l}R^{2} \\
\text { full }\end{array}$ & $a_{\text {area }}$ & $b_{\text {area }}$ & $R^{2}$ & $\begin{array}{l}p- \\
L R T\end{array}$ & $\begin{array}{l}R^{2} \\
\text { full }\end{array}$ \\
\hline Chamaephytes (Ch) & 1.9189 & 0.6873 & 0.77 & 0.000 & 0.75 & 0.7963 & 0.3762 & 0.43 & & & 24.589 & 1.1662 & 0.54 & 0.000 & 0.88 \\
\hline Lavandula stoechas L. & 1.1574 & 0.4851 & 0.70 & & & 0.7963 & 0.3762 & 0.43 & & & 0.0065 & 2.9626 & 0.91 & & \\
\hline Thymus vulgaris L. & 6.6493 & 0.9605 & 0.91 & & & & & & & & 0.8229 & 2.3530 & 0.50 & & \\
\hline Macro-phanerophytes (MPh) & 0.7856 & 0.8101 & 0.62 & 0.000 & 0.91 & 0.3596 & 0.7138 & 0.51 & 0.000 & 0.77 & 5.8458 & 1.4944 & 0.36 & 0.000 & 0.67 \\
\hline Arbutus unedo L. & 0.3973 & 1.0774 & 0.89 & & & 0.2375 & 0.8631 & 0.68 & & & 0.6284 & 1.8804 & 0.73 & & \\
\hline Buxus sempervirens L. & 1.0581 & 0.6849 & 0.59 & 0.000 & 0.62 & 0.3032 & 0.7163 & 0.54 & & & 0.9734 & 1.8072 & 0.80 & 0.000 & 0.81 \\
\hline Erica arborea L. & 0.8820 & 0.9224 & 0.82 & 0.213 & 0.48 & 0.4234 & 0.7111 & 0.70 & 0.413 & 0.41 & 7.5880 & 1.3760 & 0.55 & 0.001 & 0.69 \\
\hline Ligustrum vulgare L. & 0.3225 & 0.8106 & 0.80 & & & 0.1427 & 0.6443 & 0.84 & & & 8.0727 & 1.2580 & 0.37 & & \\
\hline Phillyrea latifolia $\mathrm{L}$. & 0.3106 & 0.7510 & 0.94 & & & 0.2502 & 0.7300 & 0.89 & & & 0.0080 & 2.8650 & 0.35 & & \\
\hline Pistacia lentiscus L. & 2.1723 & 0.8654 & 0.96 & & & 1.1897 & 0.7337 & 0.74 & & & 0.0173 & 2.9654 & 0.55 & & \\
\hline Quercus ilex L. & 0.7327 & 0.7376 & 0.83 & 0.000 & 0.83 & 0.5239 & 0.7337 & 0.84 & 0.012 & 0.81 & 1.8575 & 1.8855 & 0.61 & 0.000 & 0.79 \\
\hline Viburnum lanta $\mathrm{L}$. & 0.2872 & 0.7045 & 0.64 & & & 0.1308 & 0.5352 & 0.67 & & & 0.1068 & 2.1725 & 0.72 & & \\
\hline Viburnum tinus L. & 0.2766 & 0.9225 & 0.81 & & & 0.1349 & 0.7261 & 0.79 & & & 9.4880 & 1.3509 & 0.30 & & \\
\hline Nano-phanerophytes (NPh) & 1.2694 & 0.7610 & 0.77 & 0.053 & 0.74 & 0.7900 & 0.6942 & 0.63 & 0.060 & 0.55 & 0.9843 & 1.8759 & 0.43 & 0.000 & 0.47 \\
\hline Facultative seeders & 1.2832 & 0.8258 & 0.79 & 0.000 & 0.65 & 0.7803 & 0.8240 & 0.70 & 0.000 & 0.66 & 1.9168 & 1.6929 & 0.53 & 0.000 & 0.65 \\
\hline $\begin{array}{l}\text { Cytisophyllum sessilifolium } \\
\text { (L.) O. Lang }\end{array}$ & 0.2313 & 0.8516 & 0.74 & & & 0.2068 & 0.8514 & 0.76 & & & 0.3508 & 1.9641 & 0.09 & & \\
\hline Cytisus scoparius (L.) Link. & 1.2729 & 0.6773 & 0.89 & & & 0.8236 & 0.5315 & 0.66 & & & 0.0966 & 2.1168 & 0.31 & & \\
\hline Erica multiflora $\mathrm{L}$ & 1.4374 & 0.7916 & 0.68 & 0.181 & 0.68 & 1.1799 & 0.7531 & 0.50 & 0.009 & 0.57 & 10.171 & 1.3991 & 0.13 & 0.000 & 0.30 \\
\hline $\begin{array}{l}\text { Genista scorpius (L.) DC. in } \\
\text { Lam. et DC. }\end{array}$ & 1.9220 & 0.8807 & 0.95 & 0.360 & 0.95 & & & & & & 0.8461 & 1.8983 & 0.42 & 0.000 & 0.69 \\
\hline Spartium junceum L. & 0.5981 & 1.1340 & 0.54 & & & 0.2683 & 1.0322 & 0.63 & & & 0.1543 & 2.1752 & 0.30 & & \\
\hline Resprouters & 1.2405 & 0.7436 & 0.77 & 0.000 & 0.93 & 0.7898 & 0.6622 & 0.56 & 0.000 & 0.86 & 3.5246 & 1.6961 & 0.29 & 0.000 & 0.54 \\
\hline $\begin{array}{l}\text { Cytisus oromediterraneus } \\
\text { Ribas mart. }\end{array}$ & 2.1591 & 0.8257 & 0.97 & & & 1.3856 & 0.7712 & 0.84 & & & 1.2410 & 2.1042 & 0.84 & & \\
\hline Erica scoparia $\mathrm{L}$. & 0.9959 & 1.0594 & 0.92 & & & 0.5492 & 0.8479 & 0.86 & & & 30.709 & 1.0000 & 0.07 & & \\
\hline Quercus coccifera $\mathrm{L}$. & 0.7559 & 0.5713 & 0.73 & 0.180 & 0.73 & 0.5148 & 0.5312 & 0.79 & 0.077 & 0.78 & 0.1306 & 2.4084 & 0.27 & 0.092 & 0.21 \\
\hline Rosa canina $\mathrm{L}$. & 0.9742 & 0.9396 & 0.95 & & & & & & & & 11.157 & 1.4713 & 0.69 & & \\
\hline Seeders & 1.2796 & 0.7270 & 0.52 & 0.000 & 0.78 & 0.7777 & 0.6476 & 0.45 & 0.000 & 0.75 & 0.1376 & 2.2836 & 0.48 & 0.000 & 0.55 \\
\hline Cistus albidus L. & 0.4841 & 0.6330 & 0.68 & & & 0.2435 & 0.4986 & 0.36 & & & 0.6035 & 1.9060 & 0.46 & & \\
\hline Cistus laurifolius L. & 2.3847 & 0.7004 & 0.77 & & & 1.3792 & 0.6066 & 0.74 & & & 0.0003 & 3.5744 & 0.53 & & \\
\hline Cistus monspeliensis L & 2.3232 & 0.7917 & 0.85 & 0.000 & 0.83 & 1.6252 & 0.6947 & 0.74 & 0.000 & 0.75 & 0.0700 & 2.3642 & 0.25 & 0.001 & 0.29 \\
\hline Cistus salviifolius L. & 0.4032 & 0.8618 & 0.56 & 0.000 & 0.87 & 0.3211 & 0.7940 & 0.59 & 0.000 & 0.86 & 1.9952 & 1.7842 & 0.27 & 0.001 & 0.33 \\
\hline Rosmarinus officinalis L. & 1.9918 & 0.8348 & 0.82 & 0.002 & 0.71 & 1.3196 & 0.8929 & 0.77 & 0.001 & 0.82 & 0.1544 & 2.2532 & 0.51 & 0.000 & 0.54 \\
\hline Ulex parviflorus Pourr. & 1.1109 & 0.9279 & 0.80 & & & 0.7171 & 0.8293 & 0.68 & & & 1.9095 & 1.6006 & 0.42 & & \\
\hline
\end{tabular}


Table 7 Number of species records ( $n$ ) corresponding to each species/ group and mean absolute error $\left(\mathrm{kg} / \mathrm{m}^{2}\right)$ of species loadings calculated using either the average bulk density or the proposed method based on individual-level allometries. In all cases, benchmark loadings are those obtained from aggregation of individual biomass. Rows of species groups correspond to those species records for which a species-specific allometry is missing

\begin{tabular}{|c|c|c|c|c|c|c|c|}
\hline \multirow[b]{2}{*}{ Species/group } & \multirow[b]{2}{*}{$n$} & \multicolumn{3}{|c|}{ Fine fuel loading } & \multicolumn{3}{|c|}{ Total fuel loading } \\
\hline & & Bulk density & Up-scaled allometries & Diff. & Bulk density & Up-scaled allometries & Diff. \\
\hline Chamaephytes (Ch) & 116 & 0.0295 & 0.0280 & -0.0016 & 0.0125 & 0.0117 & -0.0009 \\
\hline Lavandula stoechas L. & 1 & 0.0052 & 0.0031 & -0.0021 & 0.0042 & 0.0023 & -0.0018 \\
\hline Thymus vulgaris L. & 33 & 0.0008 & 0.0010 & 0.0002 & 0.0008 & 0.0010 & 0.0002 \\
\hline Macro-phanerophytes (MPh) & 116 & 0.0152 & 0.0067 & -0.0085 & 0.0201 & 0.0096 & -0.0106 \\
\hline Arbutus unedo L. & 4 & 0.0017 & 0.0011 & -0.0006 & 0.0020 & 0.0013 & -0.0008 \\
\hline Buxus sempervirens L. & 29 & 0.0232 & 0.0088 & -0.0144 & 0.0594 & 0.0338 & -0.0256 \\
\hline Erica arborea $\mathrm{L}$. & 1 & 0.0201 & 0.0070 & -0.0131 & 0.0094 & 0.0022 & -0.0071 \\
\hline Phillyrea latifolia L. & 6 & 0.0016 & 0.0038 & 0.0022 & 0.0018 & 0.0042 & 0.0025 \\
\hline Pistacia lentiscus L. & 36 & 0.0118 & 0.0176 & 0.0058 & 0.0116 & 0.0149 & 0.0033 \\
\hline Quercus ilex $\mathrm{L}$. & 8 & 0.0355 & 0.0126 & -0.0228 & 0.0477 & 0.0176 & -0.0301 \\
\hline Nano-phanerophytes (NPh) & 29 & 0.0326 & 0.0251 & -0.0074 & 0.0546 & 0.0342 & -0.0204 \\
\hline Facultative seeders & 23 & 0.0019 & 0.0027 & 0.0008 & 0.0031 & 0.0044 & 0.0013 \\
\hline Cytisophyllum sessilifolium (L.) O. Lang & 1 & 0.0000 & 0.0000 & 0.0000 & 0.0000 & 0.0000 & 0.0000 \\
\hline Erica multiflora $\mathrm{L}$ & 30 & 0.0188 & 0.0124 & -0.0064 & 0.0183 & 0.0116 & -0.0067 \\
\hline Genista scorpius (L.) DC. in Lam. et DC. & 77 & 0.0155 & 0.0054 & -0.0100 & 0.0155 & 0.0054 & -0.0100 \\
\hline Spartium junceum L. & 1 & 0.0001 & 0.0000 & -0.0001 & 0.0013 & 0.0001 & -0.0013 \\
\hline Resprouters & 70 & 0.0195 & 0.0103 & -0.0092 & 0.0165 & 0.0109 & -0.0057 \\
\hline Cytisus oromediterraneus Ribas mart. & 12 & 0.0681 & 0.0502 & -0.0179 & 0.0698 & 0.0561 & -0.0137 \\
\hline Erica scoparia $\mathrm{L}$. & 1 & 0.0108 & 0.0002 & -0.0106 & 0.0075 & 0.0002 & -0.0073 \\
\hline Quercus coccifera $\mathrm{L}$. & 78 & 0.1866 & 0.0376 & -0.1490 & 0.2227 & 0.0480 & -0.1746 \\
\hline Rosa canina $\mathrm{L}$. & 12 & 0.0066 & 0.0071 & 0.0006 & 0.0066 & 0.0071 & 0.0006 \\
\hline Seeders & 20 & 0.0073 & 0.0031 & -0.0042 & 0.0041 & 0.0030 & -0.0011 \\
\hline Cistus albidus L. & 14 & 0.0024 & 0.0032 & 0.0008 & 0.0023 & 0.0029 & 0.0006 \\
\hline Cistus monspeliensis $\mathrm{L}$ & 3 & 0.0026 & 0.0017 & -0.0009 & 0.0019 & 0.0012 & -0.0007 \\
\hline Cistus salviifolius L. & 4 & 0.0006 & 0.0003 & -0.0003 & 0.0004 & 0.0002 & -0.0002 \\
\hline Rosmarinus officinalis L. & 83 & 0.0460 & 0.0224 & -0.0236 & 0.1912 & 0.0324 & -0.1588 \\
\hline Ulex parviflorus Pourr. & 17 & 0.0098 & 0.0072 & -0.0026 & 0.0103 & 0.0089 & -0.0014 \\
\hline
\end{tabular}


Table 8 Number of species records ( $n$ ) corresponding to each species/ group and relative mean absolute error (\%) of species loadings calculated using either the average bulk density or the proposed method based on individual-level allometries. In all cases, benchmark loadings are those obtained from aggregation of individual biomass. Rows of species groups correspond to those species records for which a species-specific allometry is missing

\begin{tabular}{|c|c|c|c|c|c|c|c|}
\hline \multirow[b]{2}{*}{ Species/group } & \multirow[b]{2}{*}{$n$} & \multicolumn{3}{|c|}{ Fine fuel loading } & \multicolumn{3}{|c|}{ Total fuel loading } \\
\hline & & Bulk density & Up-scaled allometries & Diff. & Bulk density & Up-scaled allometries & Diff. \\
\hline Chamaephytes (Ch) & 116 & 58.4 & 55.3 & -3.1 & 30.4 & 28.4 & -2.1 \\
\hline Lavandula stoechas L. & 1 & 80.6 & 48.4 & -32.2 & 75.2 & 42.1 & -33.1 \\
\hline Thymus vulgaris L. & 33 & 2.2 & 2.6 & 0.5 & 2.2 & 2.6 & 0.5 \\
\hline Macro-phanerophytes (MPh) & 116 & 41.1 & 18.1 & -23.0 & 25.1 & 11.9 & -13.2 \\
\hline Arbutus unedo L. & 4 & 9.4 & 6.2 & -3.2 & 5.7 & 3.6 & -2.2 \\
\hline Buxus sempervirens L. & 29 & 30.0 & 11.3 & -18.7 & 21.6 & 12.3 & -9.3 \\
\hline Erica arborea $\mathrm{L}$. & 1 & 46.4 & 16.2 & -30.2 & 16.4 & 3.9 & -12.6 \\
\hline Phillyrea latifolia $\mathrm{L}$. & 6 & 18.1 & 42.3 & 24.3 & 16.2 & 38.7 & 22.5 \\
\hline Pistacia lentiscus L. & 36 & 14.9 & 22.1 & 7.3 & 9.1 & 11.7 & 2.6 \\
\hline Quercus ilex L. & 8 & 159.9 & 57.0 & -102.9 & 154.1 & 56.8 & -97.3 \\
\hline Nano-phanerophytes (NPh) & 29 & 29.3 & 22.6 & -6.7 & 33.0 & 20.7 & -12.3 \\
\hline Facultative seeders & 23 & 9.6 & 13.8 & 4.2 & 9.6 & 13.7 & 4.1 \\
\hline Cytisophyllum sessilifolium (L.) O. Lang & 1 & 34.9 & 17.2 & -17.7 & 34.9 & 17.2 & -17.8 \\
\hline Erica multiflora $\mathrm{L}$ & 30 & 19.5 & 12.8 & -6.7 & 16.6 & 10.5 & -6.0 \\
\hline Genista scorpius (L.) DC. in Lam. et DC. & 77 & 17.1 & 6.0 & -11.1 & 17.1 & 6.0 & -11.1 \\
\hline Spartium junceum L. & 1 & 12.7 & 1.0 & -11.7 & 65.5 & 4.2 & -61.3 \\
\hline Resprouters & 70 & 45.4 & 23.9 & -21.5 & 27.8 & 18.3 & -9.5 \\
\hline Cytisus oromediterraneus Ribas mart. & 12 & 23.2 & 17.1 & -6.1 & 16.4 & 13.2 & -3.2 \\
\hline Erica scoparia $\mathrm{L}$. & 1 & 9.9 & 0.2 & -9.7 & 4.9 & 0.1 & -4.8 \\
\hline Quercus coccifera $\mathrm{L}$. & 78 & 140.9 & 28.4 & -112.5 & 120.0 & 25.9 & -94.1 \\
\hline Rosa canina $\mathrm{L}$. & 12 & 4.9 & 5.3 & 0.4 & 4.9 & 5.3 & 0.4 \\
\hline Seeders & 20 & 31.5 & 13.4 & -18.1 & 13.7 & 10.1 & -3.7 \\
\hline Cistus albidus L. & 14 & 24.6 & 32.8 & 8.1 & 18.4 & 22.9 & 4.5 \\
\hline Cistus monspeliensis $\mathrm{L}$ & 3 & 39.3 & 25.8 & -13.6 & 29.3 & 18.1 & -11.2 \\
\hline Cistus salviifolius L. & 4 & 44.0 & 21.9 & -22.1 & 32.4 & 15.1 & -17.3 \\
\hline Rosmarinus officinalis L. & 83 & 18.5 & 9.0 & -9.5 & 45.8 & 7.8 & -38.0 \\
\hline Ulex parviflorus Pourr. & 17 & 43.2 & 31.9 & -11.4 & 34.5 & 29.9 & -4.7 \\
\hline
\end{tabular}

\section{Appendix 3. Comparison of alternative loading estimation models}

We compared the performance of our proposed method of shrub loading estimation from species-level vegetation data with the approaches of Fernandes et al. (2012) and Pasalodos-Tato et al. (2015), both requiring stand-level vegetation estimates. To apply these alternative approaches, we aggregated individual-level data of the $13110 \times 10$-m plots into stand-level estimates of percent cover $(C$; in \%) and mean height $\left(H_{m}\right.$; in $\left.\mathrm{m}\right)$ in the same way as we did to obtain specieslevel data (for nine plots $C$ exceeded $100 \%$ and had to be truncated). Fernandes et al. (2012) provide the following equation to estimate shrub fine fuel loading, based on Fernandes et al. (2002):
$W_{\text {fine }}=0.555 \cdot\left(C \cdot H_{m}\right)^{0.743}$

Pasalodos-Tato et al. (2015) provide the following equation to estimate shrub total loading:

$W_{\text {total }}=a_{0}+a_{1} \cdot \ln \left(H_{m}\right)+a_{2} \cdot \ln \left(F C C_{\text {Bliss }}\right)$

where $F C C_{B l i s s}$ is the so-called Bliss transformation of shrub percentage cover:

$F C C_{\text {Bliss }}=\sin ^{-1}(\sqrt{C / 100})$

Pasalodos-Tato et al. (2015) provide $a_{0}, a_{1}$, and $a_{2}$ parameter values for several habitats of Andalusia (S of Spain). We classified the 131 field plots into habitat classes, according to the Map 
of Catalan Habitats $(1: 50,000)$ based on the review and adaptation to the Catalan territory to the EU List of Habitats of Community Interest (Carreras et al. 2016). Comparing the Catalan habitat definitions and the Andalusian habitat descriptions in Pasalodos-Tato et al. (2015), we could establish a correspondence for 95 plots, corresponding to five different Andalusian habitats (see Appendix Table 9).
We compared the predictive value of the fine fuel loading estimates of our approach based on species-level data with those obtained by applying Fernandes et al. (2012) on the set of 131 plots. Similarly, we compared the total loading estimates of our approach with those obtained applying Pasalodos-Tato et al. (2015) on the 95 for which a habitat correspondence could be established.

Table 9 Number of field plots $(n)$ classified into Catalan habitat map classes, their corresponding CORINE code and Andalusian habitat formation, description and regression coefficients $\left(a_{0}, a_{1}\right.$ and $\left.a_{2}\right)$ provided by Pasalodos-Tato et al. (2015)

\begin{tabular}{|c|c|c|c|c|c|c|c|}
\hline Number & $\begin{array}{l}\text { Catalan habitat map } \\
\text { unit }^{\mathrm{a}}\end{array}$ & CORINE code ${ }^{b}$ & Formation $^{c}$ & Andalusian habitat description ${ }^{\mathrm{c}}$ & $a_{0}$ & $a_{1}$ & $a_{2}$ \\
\hline 32 & $32 \mathrm{t}$ & 32.41 & 170 & $\begin{array}{l}\text { Associations dominated by Kernes } \\
\text { oak }\end{array}$ & -0.483 & 1.347 & 1.174 \\
\hline 16 & $32 \mathrm{~h}$ & $\begin{array}{l}32.123 / 32.211 / 32.214 / \\
32.2191 / 32.24\end{array}$ & 180 & Thicket of mastic trees & -0.483 & 1.347 & 1.174 \\
\hline 44 & $32 \mathrm{k} / 32 \mathrm{ab} / 32 \mathrm{l} / 32 \mathrm{u}$ & $\begin{array}{l}32.321 * / 32.322 * / 32.42 / 32.431 / 32.433 \\
32.4 \mathrm{~B} / 32.4 \mathrm{E}\end{array}$ & 210 & $\begin{array}{l}\text { Heathers, Erinaceae bushes and } \\
\text { related groups }\end{array}$ & 0.503 & 1.060 & 1.581 \\
\hline 1 & $32 \mathrm{x} / 32 \mathrm{n}$ & $32.432 / 32.348 / 32.36 / 32.4 \mathrm{~J}$ & $220 \mathrm{a}$ & $\begin{array}{l}\text { Rockrose shrubs and Cistaceae } \\
\text { bushes }\end{array}$ & 2.586 & 0.000 & 1.715 \\
\hline 2 & $32 w / 32 n / 32 u$ & $32.4811 * / 32.374 * / 32.375 * / 32.379 * / 32.4 \mathrm{H}$ & 240 & $\begin{array}{l}\text { Leguminous gorse shrubs and } \\
\text { related groups }\end{array}$ & 0.737 & 0.811 & 1.189 \\
\hline
\end{tabular}

${ }^{\text {a }}$ Map of Catalan Habitats (Carreras et al. 2016)

${ }^{\mathrm{b}}$ Directive 79/409/EEC

${ }^{\mathrm{c}}$ Pasalodos-Tato et al. (2015)

As before, we evaluated each approach by calculating bias, mean absolute error (MAE), and coefficient of determination $\left(\mathrm{R}^{2}\right)$ of the stand loading estimates with respect to the benchmark values, which again were loadings obtained from aggregation of individual biomass estimates. The results of the comparison are shown in Appendix Table 10 and Appendix Fig. 5. Estimates provided by the equation of Fernandes et al. (2012) most often overestimated fine fuel loading, resulting in a much larger bias and MAE compared to our approach. A possible explanation of this divergence could be that the equation of Fernandes et al. (2002) was calibrated using data from understory species in Pinus pinaster Ait. forests, where climate is wetter than our study area and hence could support species with larger bulk density such as Erica spp. and Ulex europaeus.
Table 10 Predictive performance (mean absolute error [MAE], bias, and coefficient of determination $\left[\mathrm{R}^{2}\right]$ ) of loadings calculated from species data using the proposed method or from stand-level data using the approaches of Fernandes et al. (2012) or Pasalodos-Tato et al. (2015). In all cases, benchmark loadings are those obtained from aggregation of individual biomass. Brackets for MAE and bias indicate relative values

\begin{tabular}{|c|c|c|c|c|c|}
\hline Fraction & Method & Number & $\operatorname{MAE}\left(\mathrm{kg} \mathrm{m}^{-2}\right)[\%]$ & $\operatorname{Bias}\left(\mathrm{kg} \mathrm{m}^{-2}\right)[\%]$ & $\mathrm{R}^{2}$ \\
\hline \multirow[t]{2}{*}{ Fine fuel $\left(W_{\text {fine }}\right)$} & This study & 131 & $0.074[13.7 \%]$ & $-0.025[-4.6 \%]$ & 0.879 \\
\hline & Fernandes et al. (2012) & 131 & $0.526[78.8 \%]$ & $+0.418[+77.3 \%]$ & 0.601 \\
\hline \multirow[t]{2}{*}{ Total fuel $\left(W_{\text {total }}\right)$} & This study & 95 & $0.083[10.2 \%]$ & $-0.036[-4.5 \%]$ & 0.951 \\
\hline & Pasalodos-Tato et al. (2015) & 95 & $0.275[33.8 \%]$ & $+0.102[+12.5 \%]$ & 0.696 \\
\hline
\end{tabular}


Total fuel loadings obtained using Pasalodos-Tato et al. (2015) had better predictive capacity compared to Fernandes et al. (2012), probably because climatic conditions are closer to those of our study region and the use of habitat-specific equations (Appendix Table 10; Appendix Fig. 5b). Still, their esti- mates had lower precision (higher MAE) and larger bias than the estimates obtained using our approach. Here, the divergence can be explained by uncertainties in the correspondence between Catalan and Andalusian habitats, but also to the fact that our approach accommodates better to the variation of species composition among plots assigned to the same habitat.
Fig. 5 Comparison of loadings calculated from species data using the proposed method or from stand-level data using the approaches of Fernandes et al. (2012) or Pasalodos-Tato et al. (2015). Benchmark loadings ( $y$ axis) are those obtained from aggregation of individual biomass

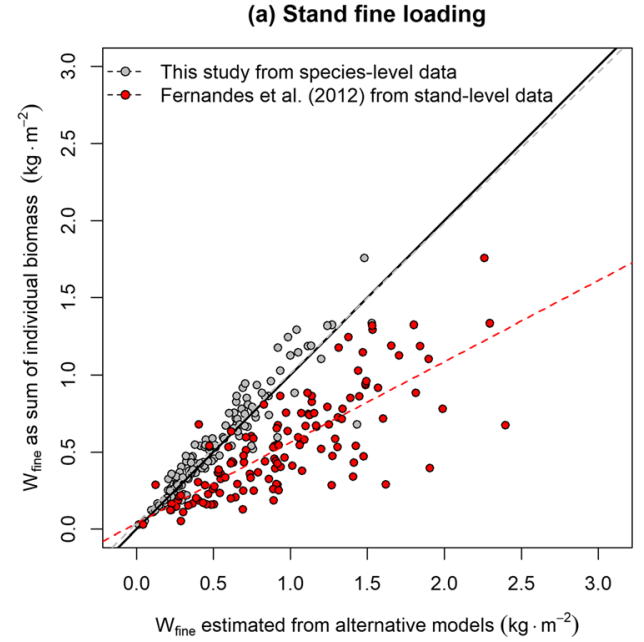

\section{References}

Armand D, Etienne M, Legrand C, Marechal J, Valette JC (1993) Phytovolume, phytomasse et relations structurales chez quelques arbustes méditerranéens. Ann Des Sci For 50:79-89. https://doi. org/10.1051/forest:19930106

Blanco-Oyonarte P, Navarro-Cerrillo RM (2003) Aboveground phytomass models for major species in shrub ecosystems of western Andalusia. For Syst 12:47-55

Bonham CD (2013) Measurements for terrestrial vegetation, 2o edn. Wiley, Oxford

Carreras J, Ferré A, Vigo J (2016) Manual dels hàbitats de Catalunya: catàleg dels hàbitats naturals reconeguts en el territori català d'acord amb els criteris establerts pel CORINE biotopes manual de la Unió Europea. Vol. IV. ISBN 9788439395553. Pp. 309

Casals P, Valor T, Besalú A, Molina-Terrén D (2016) Understory fuel load and structure eight to nine years after prescribed burning in Mediterranean pine forests. For Ecol Manag 362:156-168. https:// doi.org/10.1016/j.foreco.2015.11.050

Castro FX, Tudela A, Sebastià MT (2003) Modeling moisture content in shrubs to predict fire risk in Catalonia (Spain). Agric For Meteorol 116:49-59. https://doi.org/10.1016/S0168-1923(02)00248-4

Castro H, Freitas H (2009) Above-ground biomass and productivity in the Montado: from herbaceous to shrub dominated communities. J Arid Environ 73:506-511. https://doi.org/10.1016/j. jaridenv.2008.12.009

Castro I, Casado MÁ, Ramírez-Sanz L et al (1996) Funciones de estimación de la biomasa aérea de varias especies del matorral mediterráneo del centro de la península Ibérica. Orsis Org i Sist 11:107-116

Catchpole WR, Wheeler CJ (1992) Review estimating plant biomass : a review of techniques. Aust J Ecol 17:121-131. https://doi.org/10. 1111/j.1442-9993.1992.tb00790.x
Coll L, González-Olabarria JR, Mola-Yudego B, Pukkala T, Messier C (2011) Predicting understory maximum shrubs cover using altitude and overstory basal area in different Mediterranean forests. Eur J For Res 130:55-65. https://doi.org/10.1007/s10342-010-0395-y

Conti G, Enrico L, Casanoves F, Díaz S (2013) Shrub biomass estimation in the semiarid Chaco forest: a contribution to the quantification of an underrated carbon stock. Ann For Sci 70:515-524. https://doi. org/10.1007/s13595-013-0285-9

De Cáceres M, Casals P, Gabriel E, Castro X (2019) Package 'medfuels' and data set of shrub individual measurements collected in Catalonia, Spain. Version v1.0. Zenodo. https://doi.org/10.5281/ zenodo. 3356777

Fernandes PM (2009) Combining forest structure data and fuel modelling to classify fire hazard in Portugal. Ann For Sci 66:415-415. https:// doi.org/10.1051/forest $/ 2009013$

Fernandes P, Loureiro C, Botelho $\mathrm{H}$ et al (2002) Avaliação Indirecta da Carga de Combustível em Pinhal Bravo. Silva Lusit 10:73-90

Fernandes PM, Loureiro C, Botelho H (2012) PiroPinus: a spreadsheet application to guide prescribed burning operations in maritime pine forest. Comput Electron Agric 81:58-61. https://doi.org/10.1016/j. compag.2011.11.005

Huff S, Ritchie M, Temesgen H (2017) Allometric equations for estimating aboveground biomass for common shrubs in northeastern California. For Ecol Manag 398:48-63. https://doi.org/10.1016/j. foreco.2017.04.027

Keane RE (2015) Wildland fuel fundamentals and applications. Springer International Publishing, Cham

Kerr JT, Ostrovsky M (2003) From space to species: ecological applications for remote sensing. Trends Ecol Evol 18:299-305. https://doi. org/10.1016/S0169-5347(03)00071-5

López-Serrano FR, García-Morote A, Andrés-Abellán M, Tendero A, del Cerro A (2005) Site and weather effects in allometries: a simple approach to climate change effect on pines. 
For Ecol Manag 215:251-270. https://doi.org/10.1016/j. foreco.2005.05.014

McCullagh P, Nelder JA (1989) Generalized linear models (monographs on statistics and applied probability 37). Chapman Hall, London

Ottmar RD, Sandberg DV, Riccardi CL, Prichard SJ (2007) An overview of the fuel characteristic classification system - quantifying, classifying, and creating fuelbeds for resource planning. Can J For Res 37:2383-2393. https://doi.org/10.1139/X07-077 This article is one of a selection of papers published in the Special Forum on the Fuel Characteristic Classification System

Papió C, Trabaud L (1991) Comparative study of the aerial structure of five shrubs of Mediterranean shrublands. For Sci 37:146-159

Pasalodos-Tato M, Ruiz-Peinado R, del Río M, Montero G (2015) Shrub biomass accumulation and growth rate models to quantify carbon stocks and fluxes for the Mediterranean region. Eur J For Res 134: 537-553. https://doi.org/10.1007/s10342-015-0870-6

Paton D, Nuñez J, Bao D, Muñoz A (2002) Forage biomass of 22 shrub species from Monfragüe Natural Park (SW Spain) assessed by loglog regression models. J Arid Environ 52:223-231. https://doi.org/ 10.1006/jare.2001.0993

Paula S, Arianoutsou M, Kazanis D, Tavsanoglu C,, Lloret F, Buhk C, Ojeda F, Luna B, Moreno JM, Rodrigo A, Espelta JM, Palacio S, Fernández-Santos B, Fernandes PM, Pausas JG (2009) Fire-related traits for plant species of the Mediterranean Basin. Ecology 90: $1420-1420$

Pereira JMC, Sequeira NMS, Carreiras JMB (1995) Structural properties and dimensional relations of some mediterranean shrub fuels. Int $\mathrm{J}$ Wildland Fire 5:35-42. https://doi.org/10.1071/WF9950035

Pimont F, Dupuy JL, Rigolot E (2018) A simple model for shrub-stratafuel dynamics in Quercus coccifera L. communities. Ann For Sci 75: 1-9. https://doi.org/10.1007/s13595-018-0713-y

Porté AJ, Samalens J-C, Dulhoste R, Teissier du Cros R, Bosc A, Meredieu C (2009) Using cover measurements to estimate aboveground understorey biomass in maritime pine stands. Ann For Sci 66:307. https://doi.org/10.1051/forest/2009005

Pyne S (1984) Introduction to wildland fire management in the United States. Wiley-Interscience, New York
Ritchie MW, Zhang J, Hamilton TA (2013) Aboveground tree biomass for Pinus ponderosa in northeastern California. Forests 4:179-196. https://doi.org/10.3390/f4010179

Ruffault J, Martin-StPaul N, Pimont F, Dupuy JL (2018) How well do meteorological drought indices predict live fuel moisture content (LFMC)? An assessment for wildfire research and operations in Mediterranean ecosystems. Agric For Meteorol 262:391-401. https://doi.org/10.1016/j.agrformet.2018.07.031

Ruiz-Peinado R, Moreno G, Juarez E, Montero G, Roig S (2013) The contribution of two common shrub species to aboveground and belowground carbon stock in Iberian dehesas. J Arid Environ 91: 22-30. https://doi.org/10.1016/j.jaridenv.2012.11.002

Sabo KE, Sieg CH, Hart SC, Bailey JD (2009) The role of disturbance severity and canopy closure on standing crop of understory plant species in ponderosa pine stands in northern Arizona, USA. For Ecol Manag 257:1656-1662. https://doi.org/10.1016/j.foreco.2009. 01.006

Sah JP, Ross MS, Koptur S, Snyder JR (2004) Estimating aboveground biomass of broadleaved woody plants in the understory of Florida Keys pine forests. For Ecol Manag 203:319-329. https://doi.org/10. 1016/j.foreco.2004.07.059

Saura-Mas S, Paula S, Pausas JG, Lloret F (2010) Fuel loading and flammability in the Mediterranean Basin woody species with different post-fire regenerative strategies. Int J Wildland Fire 19:783. https://doi.org/10.1071/WF09066

Usó JL, Mateu J, Karjalainen T, Salvador P (1997) Allometric regression equations to determine aerial biomasses of Mediterranean shrubs. Plant Ecol 132:59-69. https://doi.org/10.1023/A:1009765825024

Vilagrosa A, Hernández EI, Luis VC, Cochard H, Pausas JG (2014) Physiological differences explain the co-existence of different regeneration strategies in Mediterranean ecosystems. New Phytol 201:1277-1288. https://doi.org/10.1111/nph.12584

Villanueva JA (2004) Tercer inventario forestal nacional (1997-2007). Ministerio de Medio Ambiente y Medio Rural. ICONA, Madrid

Publisher's note Springer Nature remains neutral with regard to jurisdictional claims in published maps and institutional affiliations. 